poco será acertado reparar únicamente en las semejanzas: las diferencias entre la lírica francesa y la lírica mozárabe son más y mayores (lo mismo que las diferencias entre ésta y las canciones gallegoportuguesas y castellanas). Falta en las chansons de femme la importante invocación a la madre y a las hermanas. También es evidente que mucho más que los lamentos de amor y ausencia abundan en esos estribillos las afirmaciones alegres y confiadas del amor feliz:

Biaus amis dos, tote la joie que j'ai me vient de vos.

(BARTsGH, III, núm. 35 , vs. 57-59),

y que hasta el tema de la nostalgia suele expresarse en ese tono blando e idílico:

He amis, li biauls, li doz,

trop m'aveis obliee.

(BARTSCH, II, núm. 11, vs. 10-11).

No cabe hablar, probablemente, de una gran tradición lírica conjunta de la Romania (ni tampoco, a mi ver, de un tronco único dentro de España), sino de una serie de tradiciones distintas, de las cuales unas viajaron, mientras otras quedaron confinadas en una sola región. En cuanto al lugar de origen de esas tradiciones viajeras, difícil, si no ya imposible, será precisarlo ${ }^{4}$.

El Colegio de México.

Margit Frenk Alatorre

\title{
ALGO MÁS SOBRE LA TROMPA DE PARÍS
}

Con relación a la última nota de Adolfo Salazar sobre la trompa de París (NRFH, VI, 1952, pág. 74), puede ser de algún interés

¿qué haré? era demasiado común en el habla de toda España y de Francia para que se le pueda emplear como punto de comparación entre sus líricas; pero la frecuencia del giro, empleado para las mismas situaciones, en la lírica mozárabe, la gallego-portuguesa y la francesa, es demasiado notoria. En cambio, no parece característica de la poesía lírica la doble construcción ¿̨Q Qué fareyo ou qué serad de mibi? de la jarŷa 16: "Mesquina! ¿qué faré o qué será de my?", exclama doña Urraca en la Crónica de Veinte Reyes (en la Crónica de 1344 el pasaje dice: "¿Qué faremos o qué será de nos?"; cf. Menéndez Pidal, art. cit., pág. 240, nota), y en la anónima Farsa Penada del siglo xvi: "Ah, Joãme, que faremos / ou que sera de nos?"

4 Terminada ya esta nota, he leído el interesante artículo de Aurelio RonCAGLIA sobre "una tradizione lirica pretrovadoresca in lingua volgare", $C u N$, XI, 1951, págs. 213-249; establece también el paralelo jarŷas-refrains, desde un punto de vista formal a la vez que temático, citando algunos ejemplos. Compara la jarŷa 17, ya l'i sé que otri amas, / a mibi non quieris, con el verso (no de estribillo) autrui amastes, si obliastes nos de "Bele Erembor". - El Traiés vos la, qui n'amés mie par amor y el Va t'en la qui n'aimme mie, va t'en la corresponden a un tema distinto del de $V e$, ya raqi, ve tu via... (rechazo individual de un amante infiel o desatento): los que no saben de amor no tienen derecho a participar en el baile. 
señalar que se halla mencionado tal instrumento con anterioridad al Cancionero de Ramón de Llavia, cuya primera impresión puede fecharse en 1489 ó 1490 (véase la noticia de H. SERís, Manual de bibliografia, vol. I, Syracuse, 1948, núm. 2172). En el Cancionero de Antón de Montoro ("el ropero de Córdoba"), ed. E. Cotarelo y Mori, Madrid, 19oo, pág. 59, puede leerse:

Qué cosa tan de excusar vender miel al colmenero...

$\mathrm{y}$ ante el son de las trompetas

tañer trompa de París...

El "Ropero", nacido en 1404, falleció tal vez en 1477 (véase MÉrIMÉE-Morlex, $A$ history of Spanish literature, New York, 1930, pág. 122), pero de todos modos antes del año de 1481 , según opinión de Cotarelo. Fijándonos además en el hecho de que los versos citados van dirigidos al Marqués de Santillana (1398-1458), podemos retrotraer la primera mención de la "trompa de París" hasta casi mediados del siglo xv.

University of Pennsylvania.

Joseph E. GiLlet 